\title{
HOW FTA AND NAFTA TREATIES AFFECT THE BUSINESS CYCLES SYNCHRONIZATION BETWEEN THE U.S. AND CANADA
}

\author{
Dejan Živkov" \\ Novi Sad School of Business, Novi Sad, Republic of Serbia \\ Olja Malešević
}

Faculty of Business Economics and Entrepreneurship, Belgrade, Republic of Serbia

Žana Malešević

Faculty of Business Economics and Entrepreneurship, Belgrade, Republic of Serbia

Jovana Malešević

Faculty of Business Economics and Entrepreneurship, Belgrade, Republic of Serbia

\begin{abstract}
This paper strives to gauge whether the introduction of Free Trade Agreement (FTA) and North American Free Trade Agreement (NAFTA) positively influenced business cycle synchronization between the U.S. and Canada. For computational purposes, we choose wavelet coherence and phase difference methodologies. Our results indicate that synchronization between cycles was realized much faster after the introduction of these treaties in ' $80 \mathrm{~s}$ and ' $90 \mathrm{~s}$ of the $20^{\text {th }}$ century. Also, results show that synchronization is achieved faster in crisis (after two quarters), while in tranquil periods it takes little bit longer (three quarters). Phase difference suggests that the U.S. 's business cycle is one that leading.
\end{abstract}

Key words: business cycles, FTA and NAFTA, wavelet coherence, phase difference

JEL Classification: C63, E32, F13

*dejanzivkov@gmail.com 


\section{KAKO FTA I NAFTA SPORAZUMI UTIČU NA USKLAĐIVANJE POSLOVNIH CIKLUSA IZMEĐU SAD I KANADE}

Sažetak: Ovaj rad teži da utvrdi da li su Sporazum o slobodnoj trgovini $i$ Severnoamerički sporazum o slobodnoj trgovini pozitivno uticali na usklađivanje privrednih ciklusa između SAD i Kanade. U svrhu izračunavanja, primenjene su metodologije wavelet koherencije $i$ fazne diferencije. Rezultati ukazuju da je usklađivanje privrednih ciklusa realizovano znatno brže posle stupanja na snagu ovih sporazuma u 80-im i 90-im godinama 20. veka. Takođe, rezultati pokazuju da je usklađivanje postignuto brže u kriznim periodima (posle dva kvartala), dok u mirnim periodima to traje nešto duže (tri kvartala). Fazna diferencija sugeriše da je američki poslovni ciklus taj koji prethodi kanadskom poslovnom ciklusu.

Ključne reči: poslovni ciklusi, FTA i NAFTA, wavelet koherencija, fazna diferencija

\section{INTRODUCTION}

The precursor of the NAFTA agreement was the FTA that was promoted by the U.S. Republican administration and President Ronald Reagan in the 1980s. Canada and the U.S. were the only members of FTA. NAFTA treaty was introduced on January 1, 1994 between Canada, the U.S. and Mexico. These agreements were designed to eliminate restrictions on trade and investments, and to increase higher integration between member states. Courchene (2003) contended that Canada's exports to the US doubled over 1989-2001 from $18.6 \%$ to $37.6 \%$. Other authors, such as Torres and Vela (2003), and Miles and Vijverberg (2011) agreed on an assertion that the NAFTA treaty boosted trade between its members. For instance, exports' share in total GDP increased from $14 \%$ in 1992 to $36 \%$ in 2000, while share of imports in total GDP rose from $20 \%$ in 1992 to $39 \%$ in 2000. Increase in trade and financial linkages across countries, could cause more rapid response of economies to common shocks, but closer linkages also deepen and diversify the mechanisms of transmission of international business cycles. Therefore, having a clear picture about the patterns and mechanisms that govern economic interdependence is crucial for policy makers and investors in order to evaluate the level of exposure of particular country to external shocks.

This paper tries to stipulate the level of business cycles synchronization between the U.S. and Canada, analysing the period of fifty years. Our goal is to answer how business cycles were synchronized before FTA and NAFTA came into force, and how they were harmonized afterwards. The extant literature on international trade suggests that when two economies establish a relationship 
Dejan Živkov, Olja Malešević, Žana Malešević, Jovana Malešević | 33 via trade, resources in each country are used more efficiently and as a result the consumption capacity of both economies widen. A plethora of empirical studies found that countries which trade more with each other experience higher business cycle synchronization (Frankel and Rose, 1998; Baxter and Kouparitsas, 2005; Imbs, 2004; Inklaar, Jong-A-Pin and de Haan, 2008; Kandil, 2009; Fidrmuc and Korhonen, 2010; Duval, Saraf and Seneviratne, 2016). Following many research papers which considered the topic of the business cycles synchronization, we conclude that majority of the literature analyses only the time aspect of this issue, neglecting the frequency characteristic. Berdiev and Chang (2015) asserted that synchronization of growth cycles is not unison across different frequency scales, that is, synchronization could be high at the long-run developments, whereas there may be a low degree of comovement at the short-run fluctuations for a particular sample period. Also, Herrerias and Ordonez (2014) argued that common linear approach wrongly assesses the strength of business cycles synchronization between countries, attaching significant weight on sharp movements during various phases of peaks and troughs.

Therefore, this study intends to broaden analysis beyond a simple time aspect by utilizing wavelet coherence (WTC) methodology that has been proposed by Croux, Forni and Reichlin (2001). This is a powerful signal processing technique that provides a more in-depth analysis of business cycle synchronization. In other words, WTC stretches into a long wavelet function to measure the low-frequency movements and it compresses into a short wavelet function to measure the high-frequency movements. We borrow an idea from the recent papers such as - Aguiar-Conraria and Soares (2011), Rua (2010) and Caraiani (2012), which used this methodology for gauging the strength between the business cycles. Before we commence the WTC computation process, we segregate cyclical component from the seasonally adjusted real GDP growth of the U.S and Canada, and for that purpose we apply non-parametric filter, that is, the Hodrick-Prescott filter (HP) of Hodrick and Prescott (1997).

Beside the introduction, this paper is structured as follows. Second section gives brief overview of the extant literature that is related to this topic. Third section explains methodological approach. Dataset are contained in fourth section. Fifth section presents wavelet coherence results. Seventh section concludes.

\section{BRIEF LITERATURE REVIEW AND RELATED STUDIES}

An overall impression in the extant literature is that business cycles have become less volatile since globalization, but there is no consensus on whether or not business cycles have become more synchronised after globalisation. Trancoso (2014) found a process of increasing transnational economic 
34 I HOW DO FTA AND NAFTA TREATIES AFFECTED THE BUSINESS CYCLES SINCHRONIZATION BETWEEN THE U.S. AND CANADA

interdependence within and across all economic development groups over the past six decades, revealing a significant acceleration in recent years (19962011). His results showed a trend towards economic development clustering, indicating that business cycles tend to be connected to economies which share the same degree of development. Kose, Otrok and Prasad (2012) argued that group-specific factors have become more important than global factors in driving cyclical fluctuations among industrial countries. Study of Rana, Cheng and Chia (2012) investigated the relationship between trade intensities and synchronization of business cycles in East Asia and Europe (EU-15). They found that the relationship between trade intensity and output co-movement is stronger in East Asia than in Europe. The paper of Calderón and Fuentes (2014) investigated the properties of business cycles of 71 countries (23 industrial countries and 48 emerging market economies), from 1970q1 to 2012q4. They concluded that recessions are deeper, steeper and costlier among emerging market economies (EMEs), and recessions became less costly during the globalization period (1985-2007) for industrial countries and EMEs. Konstantakopouloua and Tsionas (2014) found the evidence of common business cycles in OECD countries, covering the period from 1960 to 2010. More specifically, they claimed that there are two distinct cycles in the OECD countries - the Euro-area cycle, which includes the business cycles of Germany, France, Italy, Netherlands, Austria and Belgium, and the world cycle, which consists of the business cycles of the United States, Canada and the United Kingdom. Similar conclusion was reached by Bayoumi and Bui (2010), who explained that the international business cycle is largely driven by U.S. shocks and global shocks.

Montinari and Stracca (2016) sought the answer on how income growth rates in one country are affected by growth rates in partner countries, testing the importance of pairwise country links as well as characteristics of the receiving country. They used a sample of 15 euro-area countries, 11 non-euro area countries and other 24 non-European countries for the period 1970-2014. They concluded that trade integration fosters the spill-over of business cycles, both bilaterally and as a country characteristic (trade openness). In the manuscript of Enea, Pala and Tiganas (2015), the authors assessed business cycles' synchronization within the G7, emphasizing the role of the trade channel as a transmission vector. They discovered a stronger degree of synchronization during recessions, while in time of economic expansion there are several macro cycles corresponding to each continent: Europe, North America and the emergent Asian cycle. Inklaar et al. (2008) re-examined the relationship between trade intensity and business cycle synchronization for 21 OECD. They found that trade intensity affects synchronization, but they also reported that specialization and convergence in monetary and fiscal policies, have a similar 
Dejan Živkov, Olja Malešević, Žana Malešević, Jovana Malešević | 35 impact on business cycle synchronization as trade intensity. Study of Hanisch and Kempa (2017) investigated the spillover effects and transmission channels of the U.S. supply and demand shocks on a variety of macroeconomic variables in individual non-U.S. G7 countries. They concluded that trade channel plays a significant role in the international transmission of the U.S. shocks. However, the results indicated to substantial heterogeneities of shock transmission across the individual G7 economies.

Very few papers analysed how NAFTA treaty influenced business cycles synchronization between North American countries, and these papers took into account only the U.S. and Mexico. For instance, Torres and Vela (2003) investigated whether the business cycles of Mexico and the U.S. have converged due to increased trade integration, which was led by manufacturing. The results revealed that synchronization has stabilized the Mexican trade balance by causing fluctuations in Mexican exports and imports to converge. In addition, the volatility of the Mexican trade balance has declined. Similar inference was drawn by Chiquiar and Ramos-Francia (2005). They suggested that production-side links between Mexico and U.S. manufacturing sectors became stronger after NAFTA was enacted, which enabled higher business cycles synchronization between these countries. Their results provided an evidence that the positive effect of trade on business-cycle synchronization could also hold for trade between industrial and less developed countries.

\section{METHODOLOGICAL APPROACH}

This section explains the wavelet coherence methodology, which permits the evaluation of the connection between business cycles of NAFTA members in both time-frequency spaces. In particular, wavelet methodology estimates the spectral characteristics of a time-series as a function of time, revealing how the different periodic components of a specific time-series evolve over time. Referring to Rua and Nunes (2009), the continuous wavelet transform, $W_{x}(u, s)$, can be obtained by projecting a specific wavelet $\psi($.$) onto the$ examined time series $x(t) \in L^{2}(\mathbb{R})$ by the following expression:

$$
W_{x}(u, s)=\int_{-\infty}^{\infty} x(t) \frac{1}{\sqrt{s}} \bar{\psi} \overline{\left(\frac{t-u}{s}\right)} d t
$$

where $u$ represents the position of the wavelet in the time domain while $s$ portrays the position in the frequency domain. Equation (1) implies that information on time and frequency can be simultaneously obtained by mapping the original time series into a function of $\mathrm{u}$ and $\mathrm{s}$ in the wavelet transform.

Vacha and Barunik (2012) asserted that squared wavelet coherence gauges the local linear correlation between two stationary time series at each scale, and it is equivalent to the squared correlation coefficient in linear regression. According SCHOOL OF BUSINESS, 2/2018, 31-44 
36 I HOW DO FTA AND NAFTA TREATIES AFFECTED THE BUSINESS CYCLES SINCHRONIZATION BETWEEN THE U.S. AND CANADA

to Torrence and Webster (1999), WTC can be pictured as a squared absolute value of the smoothed cross wavelet spectra normalized by the product of the smoothed individual wavelet power spectra of each selected time series. The cross wavelet transform of two time-series, $\mathrm{x}(\mathrm{t})$ and $\mathrm{y}(\mathrm{t})$, is determined as $W_{x y}(u, s)=W_{x}(u, s) \overline{W_{y}}(u, s)$, wherein $W_{x}$ and $W_{y}$ are the wavelet transforms of $\mathrm{x}$ and $\mathrm{y}$, respectively. The squared wavelet coherence coefficient is given as follows:

$$
R^{2}(u, s)=\frac{\left|s\left(s^{-1} W_{x y}(u, s)\right)\right|^{2}}{s\left(s^{-1}\left|W_{x}(u, s)\right|^{2}\right) S\left(s^{-1}\left|W_{y}(u, s)\right|^{2}\right)}
$$

where $S($.$) stands for a smoothing operator and s$ is a wavelet scale. The squared wavelet coherence coefficient takes values in a range $0 \leq R^{2}(u, s) \leq 1$, where values near zero point to weak correlation, while values near one indicate strong correlation. WTC is estimated by applying the Monte Carlo simulation methods.

One shortcoming of WTC methodology is that it cannot determine whether dependence between two time-series is positive or negative because the wavelet coherence is squared. Therefore, we employ wavelet coherence phase differences, which depicts details about the delays in the oscillation between the two time-series under study. Following Torrence and Webster (1999), the wavelet coherence phase difference is defined as follows:

$\phi_{x y}(u, s)=\tan ^{-1}\left(\frac{\Im\left\{s\left(s^{-1} W_{x y}(u, s)\right)\right\}}{\Re\left\{S\left(s^{-1} W_{x y}(u, s)\right)\right\}}\right)$

where $\mathfrak{I}$ and $\mathfrak{R}$ are the imaginary and real parts, respectively, of the smooth power spectrum. Phase difference between two series (x, y) is described by vector arrows on the wavelet coherence plots. Vacha and Barunik (2012) explained that right (left) pointing arrows indicate that the time series are inphase (anti-phase) or are positively (negatively) correlated. If arrows point to the right and up, the second variable is lagging and if they point to the right and down, the second variable is leading. Reversely, if arrows point to the left and up, the second variable is leading and if arrows point to the left and down, the second variable is lagging.

\section{DATASET}

The dataset, used for the research, comprises quarterly data of seasonally adjusted real GDP of Canada and the U.S. The full sample encompasses the period of fifty years, i.e. from Q1 1967 to Q1 2017, and data was recovered from OECD statistics. In order to separate the cyclical component from the trend in the growth rates, we use the Hodrick-Prescott filter (HP) of Hodrick 
Dejan Živkov, Olja Malešević, Žana Malešević, Jovana Malešević | 37 and Prescott (1997), a technique that was usually applied for this type of problem in the international literature (Degiannakis, Duffy and Filis, 2014; Aslanidis, 2010; Chionis and Leon, 2009). Following the same papers, we set the smoothness parameter $(\lambda)$ to be 1600 . Employing wavelet coherence methodology, we analyse dynamic nexus in three frequency levels. This allows us to view interdependence in different time horizons, which corresponds to: scale 1 (2-4 quarters), scale 2 (4-8 quarters) and scale 3 (8-16 quarters). First scale observes short term dynamics, midterm is represented by the second scale, while third scale corresponds to long term dynamics.

Table 1 illustrates summary statistics for business cycles obtained via HP filter, while Figure 1 discloses dynamics of cyclical component depicted vis-à-vis each other. The mean values are not presented in the Table, since all cycles oscillate around zero. According to descriptive statistics, the U.S. has slightly higher variability of growth cycles than Canada. Canada has the lowest minimum, whereas the U.S. has the highest maximum.

Table 1

Descriptive statistics of business cycles filtered by Hodrick-Prescott method

\begin{tabular}{lllllll}
\hline & Minimum & Maximum & $\begin{array}{l}\text { Standard } \\
\text { deviation }\end{array}$ & Skewness & Kurtosis & $\begin{array}{c}\text { Number of } \\
\text { observation }\end{array}$ \\
\hline Canada & -2.559 & 1.894 & 0.745 & -0.265 & 3.490 & 201 \\
USA & -2.542 & 3.099 & 0.754 & -0.141 & 5.124 & 201 \\
\hline
\end{tabular}

Note. Calculated by the authors.

Visual inspection of Figure 1 gives superficial appraisals of how well business cycles are synchronized of selected countries and it certainly cannot provide the answer whether business cycles are more harmonized after FTA and NAFTA trade treaties took place. Therefore, in the next Section we present the wavelet coherence results which are significantly richer in details. 


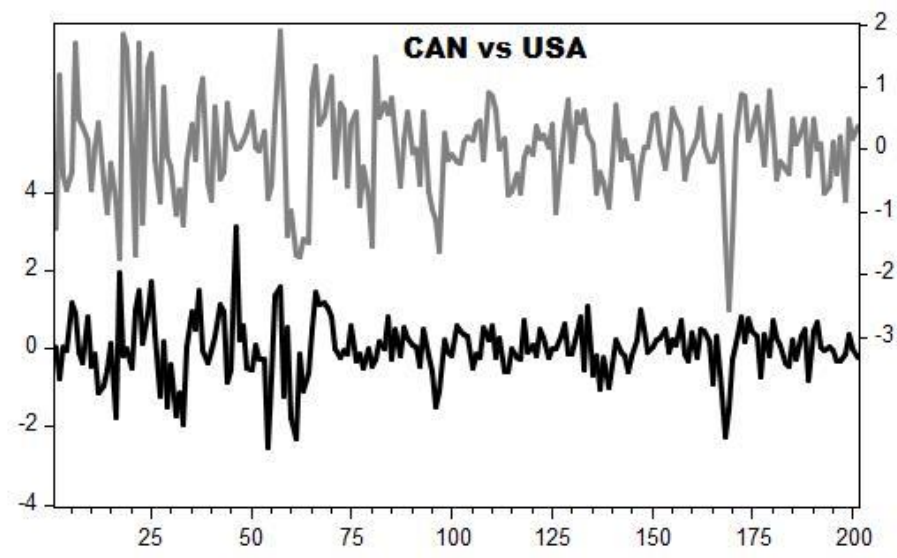

Figure 1 Extracted cyclical components by the HP filter

Note. Grey and black lines represent seasonally adjusted business cycles of Canada and the U.S., respectively.

\section{WAVELET COHERENCE FINDINGS}

Wavelet coherence technique can provide answer on how well business cycles are synchronized regarding both time-frequency spaces. WTC plot $^{\dagger}$, in Figure 2, depicts the strength of coherence via three different wavelet scales between business cycles of the U.S. and Canada. Horizontal axis on WTC plot denotes time component, while the left vertical axis represents frequency component, which goes up 16 quarters, equal to four years. Colour pallet, at right vertical axis, points to the strength of the co-movement between the business cycles, whereby light-grey shades signify low coherence, while dark-grey shades point to higher coherence. Delineated dark-grey islands denote very high coherence. The cone of influence marks the area of statistical significance at 5\% level. This curved boundary constrains the region of the wavelet spectrum which is influenced by edge effects. According to Torrence and Compo (1998), outside the cone of influence edge effects become important and these values should be interpreted with great caution.

Looking at Figure 2, it can be seen that high coherence areas are heterogeneously distributed across different time periods and wavelet scales, which justify the usage of WTC approach. It is obvious that dark-grey areas are most dominant colour, which indicates to high coherence between observed business cycles. This is not surprising taking into account that these economies

\footnotetext{
† All WTC computations were done in ' $\mathrm{R}$ ' software.
} 
Dejan Živkov, Olja Malešević, Žana Malešević, Jovana Malešević | 39 have high similarities in countries' industrial composition, and they also foster close ties in terms of financial openness, human capital mobility and bilateral trade since World War II. These factors are listed by Ductor and Leiva-Leon (2016) as key determinants necessary for high business cycles interdependence. In addition, some authors such as Enea et al. (2015) and Konstantakopouloua and Tsionas (2014) asserted that North American economies - the U.S. and Canada, along with the United Kingdom, resemble each other so much that they form one distinguishable North American cycle, which in great deal dictates oscillations of the world business cycle. More specifically, our WTC plot reveals that in the period between '70s and ' 80 s, i.e. before FTA and NAFTA treaties, high coherence areas stretch from third quarter and all the way to seventh quarter. Such long-lasting high business cycles correlation most likely happened, at that time, due to world economy recession, which was an aftermath of the oil price surge that occurred in two separate occasions. First one began in October 1973 when OPEC proclaimed oil embargo as a response to United States' support for Israel during the Yom Kippur War. Second one took place in 1979 due to decreased oil output in the wake of the Iranian Revolution. In the second oil crisis, oil price increase was induced by widespread panic and the negative expectations regarding the future oil prices. As a consequence, price of crude oil had more than doubled over the next 12 months, but world oil production decreased by only $4 \%$.

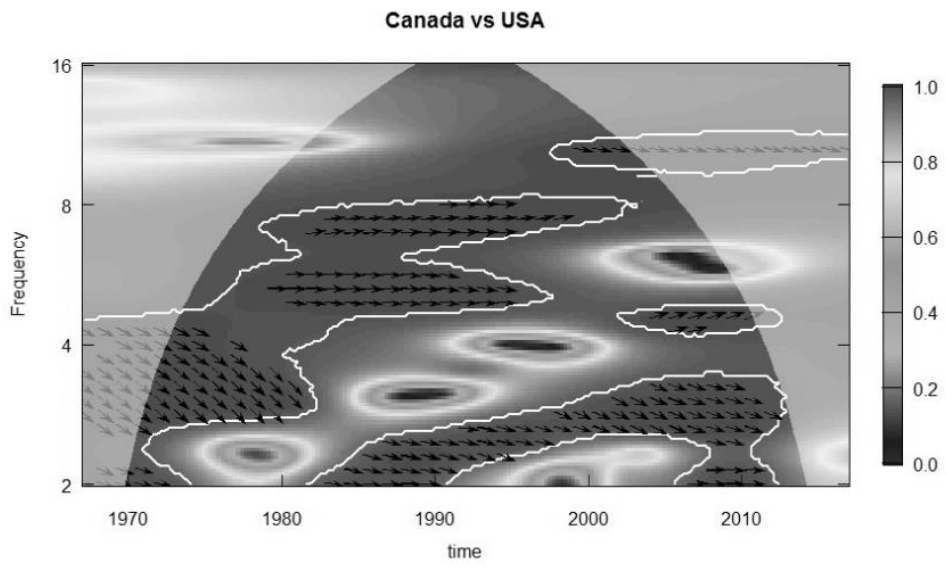

Figure 2 Wavelet square coherence between business cycles of the US and Canada.

Note. Calculated by the authors. Left vertical axis represents frequency component, which goes up to fourth scale (16 quarters). The strength of the co-movement is measured via black and white surface, were light shaded surfaces signify low coherence, while dark-shaded surfaces point to a higher coherence. 
40 | HOW DO FTA AND NAFTA TREATIES AFFECTED THE BUSINESS CYCLES SINCHRONIZATION BETWEEN THE U.S. AND CANADA

After FTA introduction in ' 80 s, it can be seen in WTC plot that synchronization between cycles was realized much faster - after two quarters. This is in line with the previous studies, such as Montinari and Stracca (2016), Enea et al. (2015), Inklaar et al. (2008), who underlined that trade integration enhances business cycle synchronization. In addition, during the ' $90 \mathrm{~s}$, when NAFTA treaty came into force, we also find dark-grey areas at relatively high wavelet frequencies, i.e. between second and third quarter. It indicates that higher trade closeness, which continued with NAFTA treaty, resumes to influence faster and stronger business cycle harmonization between the U.S. and Canada.

Phase arrows in the dark-grey surfaces can indicate the phase pattern as well as lead/lag relationship between particular business cycles. Most phase arrows are directed to straight right or to down-right. When phase arrows point to right, it means that analysed series are positively correlated, while when they are tilted to right-down it indicates that second variable, i.e. the U.S. has the leading role. This is in line with the findings of Hanisch and Kempa (2017), who documented that the U.S. economy has major and leading role when it comes to the shock spillover effect to other neighbouring and more distant world economies.

During the period that covers World financial crisis (WFC) and the subsequent Sovereign debt crisis (SDC) in the U.S. (2007-2011), we find that high coherence areas begin at high frequencies (second quarter) and lasted continuously to relatively low frequency (fifth quarter). High coherence areas encompass several wavelet scales during WFC and SDC, which indicates that economic shocks during that period were very severe, profound and that they lasted for the extended period of time. The prolonged high coherence pattern during WFC and SDC is similar to the occurrences in '70s. Also, business cycles were in phase during WFC and SDC, since all phase arrows point to either straight right od down-right, suggesting that the U.S. business cycles had leading role at that time, which is not surprising taking into account the origin of WFC. These results are consistent with other studies that analysed WFC period. For instance, Botha (2010) concluded that large shocks induce high business cycle synchronisation, whereby the timing and magnitude of major changes in economic activity appear to be similar. Also, Enea et al. (2015) claimed that during times of recession, the G7 countries have displayed similar synchronization patterns. The study of Aguiar-Conraria and Soares (2011) investigated European continent, analysing business cycles synchronization between EU15 and EU12 countries. They brought out a notion that, when global crisis hit hard and simultaneously several countries, they behaved as if they were highly synchronized. 


\section{SUMMARY AND CONCLUSION}

Dejan Živkov, Olja Malešević, Žana Malešević, Jovana Malešević | 41

This paper strives to determine whether FTA and NAFTA treaties positively affected business cycles synchronization between the U.S. and Canada. The observed period comprised fifty years, and business cycles are singled out via Hodrick-Prescott filter. In order to do more thorough analysis, we observe business cycles synchronization via different frequency scales, using wavelet coherence and phase difference methodologies.

We find heterogeneous patterns of wavelet coherence in WTC plot, which justifies the usage of this approach. WTC results indicate the presence of high coherence at the third quarter level during '70s, i.e. when FTA and NAFTA were not in force, which corresponds to the first and second oil crisis. FTA agreement is promoted in ' 80 s, while NAFTA was signed in 1994 and the period afterward was undoubtedly marked by increased bilateral trade volumes between its members. Our results indicate that synchronization between cycles was realized much faster (in two quarters period) after FTA introduction in ' 80 s. Also, during '90s, when NAFTA treaty was introduced, we also find darkgrey areas between second and third quarter, which is in compliance that higher trade closeness positively influenced faster and stronger business cycle harmonization between the U.S. and Canada. In addition, the results clearly show that during turbulent periods, like first and second oil crisis and particularly during WFC, the business cycles commence to display similar downward synchronization patterns, and that is reflected in their strong and prolonged coherence.

This paper could serve well for various investors and policy makers who are interested in North American region to gain a hint regarding the level of exposure of particular country to external shocks. Our findings show that spillover shocks commonly originate from the U.S. economy toward Canadian economy, whereby business cycles reach synchronization usually after 2-3 quarters. Synchronization of cycles is achieved faster in crisis periods (after two quarters), whereas in tranquil periods it takes little bit longer (three quarters). Since Canadian economy lagging for most of the time, Canadian investors can better prepare their business projects for upcoming shocks that come from the U.S. economy.

\section{REFERENCES}

Aguiar-Conraria, L., \& Soares, M. J. (2011). Business cycle synchronization and the Euro: A wavelet analysis. Journal of Macroeconomics, 33(3), 477-489. 
42 I HOW DO FTA AND NAFTA TREATIES AFFECTED THE BUSINESS CYCLES SINCHRONIZATION BETWEEN THE U.S. AND CANADA

Aslanidis, N. (2010). Business Cycle Synchronization between the CEEC and the Euro-Area: Evidence from Threshold Seemingly Unrelated Regressions. Manchester School, 78(6), 538-55.

Barunik, J., \& Vacha, L. (2013). Contagion among Central and Eastern European Stock Markets during the Financial Crisis. Finance a úvěrCzech Journal of Economics and Finance, 63(5), 443-453.

Baxter, M., \& Kouparitsas, M. (2005). Determinants of business cycle comovement: a robust analysis. Journal of Monetary Economics, 52(1), $113-157$.

Bayoumi, T., \& Bui, T. (2010). Deconstructing the international business cycle: why does a U.S. sneeze give the rest of the world a cold? IMF Working Paper, No. 10/239.

Berdiev, A. N., \& Chang, C. P. (2015). Business cycle synchronization in AsiaPacific: New evidence from wavelet analysis. Journal of Asian Economics, 37, 20-33.

Botha, I. (2010). A comparative analysis of the synchronization of business cycles for developed and developing economies with the world business cycle. South African Journal of Economics, 78(2), 192-207.

Calderón, C., \& Fuentes, J. R. (2014). Have business cycles changed over the last two decades? An empirical investigation. Journal of Development Economics, 109, 98-123.

Caraiani, P. (2012). Stylized facts of business cycles in a transition economy in time and frequency. Economic Modelling, 29(6), 2163-2173.

Chionis, D., \& Leon, C. (2009). Synchronization of the Polish and European Business Cycles. Journal of Economic Asymmetries, 6(1), 119-130.

Chiquiar, D. \& Ramos-Francia, M. (2005). Trade and business-cycle synchronization: evidence from Mexican and U.S. manufacturing industries. North American Journal of Economics and Finance, 16(2), 187-216.

Courchene, J. T. (2003). FTA at 15, NAFTA at 10: a Canadian perspective on North American integration. North American Journal of Economics and Finance, 14(2), 263-285.

Croux, C., Forni, M., \& Reichlin, L. (2001). A measure of comovement for economic variables: theory and empirics. Review of Economics and Statistics, 83(2), 232-241. 
Dejan Živkov, Olja Malešević, Žana Malešević, Jovana Malešević | 43

Degiannakis, S., Duffy, D., \& Filis, G. (2014). Business cycle synchronization in EU: A time-varying approach. Scottish Journal of Political Economy, 61(4), 348-370.

Ductor, L., \& Leiva-Leon, D. (2016). Dynamics of global business cycle interdependence. Journal of International Economics, 102, 110-127.

Duval, R., Li, N., Saraf, R., \& Seneviratne, D. (2016). Value-added trade and business cycle synchronization. Journal of International Economics, 99(11), 251-262.

Enea, S. F., Pala, S., \& Tiganas, C. (2015). G7 countries - advocates of the global business cycle. Procedia Economics and Finance, 20, 193 - 200.

Imbs J, (2004). Trade, specialization and synchronization. Review of Economics and Statistics, 86(3), 723-734.

Inklaar, R., Jong-A-Pin, R., \& de Haan, J. (2008). Trade and business cycle synchronization in OECD countries - a re-examination. European Economic Review, 52(4), 646-666.

Kandil, M. (2009) Spillover Effects of U.S. Business Cycles on Latin America and the Caribbean. Journal of Economic Issues, 18(4), 971-996.

Konstantakopouloua, I., \& Tsionas, E. G. (2014). Half a century of empirical evidence of business cycles in OECD countries. Journal of Policy Modeling, 36(2), 389-409.

Kose, M. A., Otrok, C., \& Prasad, E. (2012). Global business cycles: Convergence or decoupling? International economic review, 53(2), 511538.

Fidrmuc, J., \& Korhonen, I. (2010). The impact of the global financial crisis on business cycles in Asian emerging economies. Journal of Asian Economics, 21(3), 293-303.

Frankel, J. A., \& Rose, A. K. (1998). The endogeneity of the optimum currency area criteria. Economic Journal, 108(449), 1009-1025.

Hanisch, M., \& Kempa, B. (2017). The international transmission channels of US supply and demand shocks: Evidence from a non-stationary dynamic factor model for the G7 countries. North American Journal of Economics and Finance, 42, 70-88.

Herrerias, M. J., \& Ordonez, J. (2014). If the United States sneezes, does the world need "pain-killers"? International Review of Economics and Finance, 31, 159-170. 
44 I HOW DO FTA AND NAFTA TREATIES AFFECTED THE BUSINESS CYCLES SINCHRONIZATION BETWEEN THE U.S. AND CANADA

Hodrick, R., \& Prescott, E. (1997). Postwar U.S. business cycles: an empirical investigation. Journal of Money, Credit and Banking, 29(1), 1-16.

Miles, W., \& Vijverberg, C. P. C. (2011). Mexico's Business Cycles and Synchronization with the USA in the Post-NAFTA Years. Review of Development Economics, 15(4), 638-650.

Montinari, L., \& Stracca, L. (2016). Trade, finance or policies: What drives the cross-border spill-over of business cycles? Journal of Macroeconomics, 49, 131-148.

Rana, P. B., Cheng, T., \& Chia, W. M. (2012). Trade intensity and business cycle synchronization: East Asia versus Europe. Journal of Asian Economics, 23, 701-706.

Rua, A., \& Nunes, L. C. (2009). International co-movement of stock market returns: a wavelet analysis. Journal of Empirical Finance, 16(4), 632639.

Rua, A. (2010). Measuring comovement in the time-frequency space. Journal of Macroeconomics, 32(2), 685-691.

Torrence, C., \& Compo, G. P. (1998). A practical guide to wavelet analysis. Bulletin of the American Meteorological Society, 79(1), 61-78.

Torrence, C., \& Webster, P. J. (1999). Interdecadal changes in the ENSOmonsoon system. Journal of Climate, 12(8), 2679-2690.

Torres, A., \& Vela, O. (2003). Trade integration and synchronization between the business cycles of Mexico and the United States. North American Journal of Economics and Finance, 14(3), 319-342.

Trancoso, T. (2014). Emerging markets in the global economic network: Real(ly) decoupling? Physica A: Statistical Mechanics and its Applications, 395, 499-510.

Vacha, L., \& Barunik, J. (2012). Co-movement of energy commodities revisited: Evidence from wavelet coherence analysis. Energy Economics, 34(1), 241-247.

Delivered: 09.02.2019.

Accepted: 19.03.2019. 